\title{
The Influence of Brand Image, Service Quality, Price Perception and Trust on the Purchase Decision of Welding Workshop Welding Www.Kanopirumah.Com
}

\author{
Juhaeri \\ Universitas Pamulang \\ E-mail: juhaeri@unpam.ac.id
}

(Received: June-2018; Reviewed: July-2018; Accepted: August-2018;

Avalaibel Online: August-2018; Published: September-2018)

c) (7) (8) This is an open access article distributed under the Creative Commons Attribution License

\begin{abstract}
Www.kanopirumah.com is a business that is engaged in the welding workshop business. To determine the effect of brand image on purchasing decisions, service quality on purchasing decisions, price perceptions of purchasing decisions, trust in purchasing decisions, and to know together with the influence of a brand image, service quality, price perceptions and trust in purchase decisions for welding shop services www.kanopirumah.com. This research is quantitative research. The population in this study are consumers who conduct transactions at the welding workshop www.Kanopirumah.Com. in this study as many as 100 consumers. Data collection methods in this research are observation, documentation study, and literature study. The method of data analysis is a simple linear regression test, product-moment correlation test, determination test, and hypothesis test (t-test). Data processing using Statistical Social Science Program (SPSS) version 22.00. The results showed that (1) Brand image influenced purchasing decisions with a t-test value of 2.329, sig. $0.022<\alpha=0.05$, thus proving the hypothesis that the brand image influences the purchase decision. (2) Quality of service influences purchasing decisions with a ttest value of 2.277 , sig. $0.025<\alpha=0.05$, thus proving the hypothesis that service quality affects the purchasing decision. (3) Price perception influences purchasing decisions with a t-test value of 3.093, sig. $0.003<\alpha=0.05$, thus proving the hypothesis that price perception influences the purchase decision. (4) trust influences purchasing decisions with a t-test value of 3.215, sig. $0.002<\alpha=0.05$, thus proving the hypothesis that states' trust has an effect on purchasing decisions. (5) Brand image, service quality, price perception, and trust affect purchasing decisions.
\end{abstract}

Keywords: Brand image, service quality, price perception, trust, purchasing decisions

\section{INTRODUCTION}

The development of the business world at this time with the enactment of free trade has an impact on increasingly fierce business competition, this requires business people to be more observant and sharp in seeing opportunities that exist and see the behavior of consumers who 
are the target market (Diza, Moniharapon, \& Ogi, 2016; Peter \& Olson, 2014; Selang, 2013; Subianto, 2007; Sumarwan, 2014). The rapid development and competition in the field of trade, demands a variety of innovations in marketing products. The company is also expected to be in a competitive condition and continue to be demanded to improve and or adjust brand image, price and promotion to the desires of consumers (Achidah, Hasiolan, \& Warso, 2016; Amrullah \& Agustin, 2016; Komalasari, 2012; Soegoto, Mandey, \& Sari, 2014; Sumiati, 2016)

Marketing managers who spearhead the marketing department should know how consumer behavior in making purchasing decisions will be the key to success in marketing activities (Kartikasari, Arifin, \& Hidayat, 2013; Mamahit, Soegoto, \& Tumbuan, 2015; Setiadi, 2003; Sutisna, 2003). Company management is very important to understand the promotional mix used, consumer price perceptions of products and locations, especially in terms of attracting consumers' attention and determining purchasing decisions. After the purchase decision will be reviewed in terms of customer satisfaction which is an important and main aspect of the sale (Brata, 2003; Giese \& Cote, 2000; Puccinelli et al., 2009). Various factors can influence consumers in entrusting places to shop. A good brand image can be used as a strength by retail companies to attract consumers. Cheap and affordable product prices with consumer purchasing power will affect the consumer's purchasing decisions (Fristiana, 2012; Kotler dan Amstrong, 2008; Nurmadina, 2016; Riyono \& Budiharja, 2016; Suryonaningsih, 2016).

Industrial development in Tangerang has increased so that there are many business opportunities. One of the lucrative businesses in the welding shop business (Sunarsi, 2018). www.kanopirumah.com is a business engaged in the business of welding shops, for the manufacture of canopies, fences, trails, rallying stairs, metal doors that are applied to housing, offices, shops, businesses, and warehouses. Supported by experienced experts in their fields, so they are able to do good work from small to large scale.

The total income of www.kanopirumah.com in 2018 has decreased in the last six months. This has an impact on the amount of income decreased by an average of $0.68 \%$. This decrease in income was due to the consumer's purchasing decisions for the manufacture of canopies, fences, trails, rallying stairs, metal doors to the workshop www.kanopirumah.com which is relatively small. The purchase decision is to choose from two or more choices of consumers on a purchase. Every day consumers make various decisions to meet their needs (Asshiddieqi \& Mudiantono, 2012; Fitria, 2014; Haviluddin;, 2014; Kotler dan Amstrong, 2008; Schiffman \& Kanuk, 2007; Wijaya, Sunarti, \& Pangestuti, 2018). But sometimes, in making these decisions do not think about how to make the right decision and what is involved in the purchase decision making process. In decision making, alternative choices for consumers are also needed, so that there are appropriate alternative choices in meeting their daily needs.

\section{METHOD}

This research is quantitative research. The population in this study are consumers who conduct transactions at the welding workshop www.Kanopirumah.Com. in this study as many as 100 consumers. Data collection methods in this research are observation, documentation study, and literature study. The method of data analysis is a simple linear regression test, product-moment correlation test, determination test, and hypothesis test (t-test). Data processing using Statistical Social Science Program (SPSS) version 22.00. 


\section{RESULT AND DISCUSSION}

The object of this research is Las Bengkel www.Kanopirumah.com which is located on Jl. Military Kodiklat Buaran village, Rt. 02/03, Kota Tangerang Selatan. Things to be discussed in this study are the influence of brand image on purchasing decisions, service quality on purchasing decisions, price perceptions of purchasing decisions, trust in purchasing decisions, and to find out together the influence of brand image, service quality, price perceptions and trust on the decision to purchase welding shop services www.kanopirumah.com.

\section{Description of Individual Characteristics}

The results of this study indicate that the welding workshop consultants www.kanopirumah.com $65.0 \%$ are women and more than $35.0 \%$ of men with homes. This shows that more female consumers make purchases at the welding shop www.kanopirumah.com to meet the needs of their homes such as: making canopies, fences, trellis, rallying stairs, metal doors, and others for their homes.

Based on the age of the respondents showed that most of the age group 25-35 years, which is as much as $55.0 \%$. This shows that at the time of conducting this research many consumers were found aged 25-35 years who needed welding shop services.

Based on the education of respondents, the most number is the last education $\mathrm{S} 1$, which is as much as $56.0 \%$. This shows that the welding shop consumers www.kanopirumah.com is dominated by consumers with the latest education S1 who need welding workshop services for their various needs.

Based on work shows that the majority of consumers who use the services of welding shop www.kanopirumah.com work as private employees. Judging from the results of the study showed the work of consumers welding shop www.kanopirumah.com as much as $50.0 \%$.

\section{Description of Research Variables}

Here are the results of the brand image variable, the answer choices are divided into 5 namely strongly disagree (SD), disagree (D), neutral (N), agree (A), strongly agree (SA)

Table 1.

Descriptive Statistics of Brand Image

\begin{tabular}{|c|c|c|c|c|c|c|c|c|c|}
\hline \multirow[t]{2}{*}{ No } & \multirow[t]{2}{*}{ Statement } & \multicolumn{5}{|c|}{$\begin{array}{l}\text { Percentage of consumer } \\
\text { responses }\end{array}$} & \multirow[t]{2}{*}{ Score } & \multirow[t]{2}{*}{ Mean } & \multirow[t]{2}{*}{ Category } \\
\hline & & SD & D & $\mathbf{N}$ & $\mathbf{A}$ & SA & & & \\
\hline 1 & $\begin{array}{l}\text { Las Workshop } \\
\text { www.kanopirumah.com is } \\
\text { well known }\end{array}$ & 4,0 & 9,0 & 45,0 & 36,0 & 6,0 & 331,0 & 3,31 & $\begin{array}{l}\text { High } \\
\text { enough }\end{array}$ \\
\hline 2 & $\begin{array}{l}\text { The reputation of the } \\
\text { welding shop } \\
\text { www.kanopirumah.com is } \\
\text { well known }\end{array}$ & 3,0 & 8,0 & 46,0 & 34,0 & 9,0 & 338,0 & 3,38 & $\begin{array}{l}\text { High } \\
\text { enough }\end{array}$ \\
\hline 3 & $\begin{array}{l}\text { The logo of the welding shop } \\
\text { www.kanopirumah.com is } \\
\text { easy to remember }\end{array}$ & 2,0 & 6,0 & 31,0 & 40,0 & 21,0 & 372,0 & 3,72 & High \\
\hline \multicolumn{8}{|c|}{ Mean of Brand Image } & 3,47 & High \\
\hline
\end{tabular}


The following are the results of the study of service quality variables, the answer choices are divided into 5 namely strongly disagree (SD), disagree (D), neutral (N), agree (A), strongly agree (SA)

Table 2.

Descriptive Statistics of Service Quality

\begin{tabular}{|c|c|c|c|c|c|c|c|c|c|}
\hline \multirow[t]{2}{*}{ No } & \multirow[t]{2}{*}{ Statement } & \multicolumn{5}{|c|}{$\begin{array}{l}\text { Percentage of consumer } \\
\text { responses }\end{array}$} & \multirow[t]{2}{*}{ Score } & \multirow[t]{2}{*}{ Mean } & \multirow[t]{2}{*}{ Category } \\
\hline & & SD & D & $\mathbf{N}$ & $\mathbf{A}$ & SS & & & \\
\hline 1 & $\begin{array}{l}\text { Welding employees at } \\
\text { www.kanopirumah.com } \\
\text { provide clear information } \\
\text { to consumers }\end{array}$ & 1,0 & 8,0 & 23,0 & 55,0 & 13,0 & 371,0 & 3,71 & High \\
\hline 2 & $\begin{array}{l}\text { The welding shop } \\
\text { www.kanopirumah.com } \\
\text { makes it easy for } \\
\text { consumers to contact him }\end{array}$ & 4,0 & 12,0 & 40,0 & 31,0 & 13,0 & 337,0 & 3,37 & $\begin{array}{l}\text { High } \\
\text { enough }\end{array}$ \\
\hline 3 & $\begin{array}{l}\text { Welding employees at } \\
\text { www.kanopirumah.com } \\
\text { understand the needs of } \\
\text { consumers }\end{array}$ & 1,0 & 8,0 & 23,0 & 55,0 & 13,0 & 371,0 & 3,71 & High \\
\hline 4 & $\begin{array}{l}\text { Welding employees at } \\
\text { www.kanopirumah.com } \\
\text { are able to do work on } \\
\text { time }\end{array}$ & 3,0 & 13,0 & 45,0 & 31,0 & 8,0 & 328,0 & 3,28 & $\begin{array}{l}\text { High } \\
\text { enough }\end{array}$ \\
\hline 5 & $\begin{array}{l}\text { Equipment used by } \\
\text { modern welding shop } \\
\text { www.kanopirumah.com }\end{array}$ & 5,0 & 4,0 & 21,0 & 52,0 & 18,0 & 374,0 & 3,74 & High \\
\hline \multicolumn{7}{|c|}{ Mean of Service Quality } & & 3,56 & Tinggi \\
\hline
\end{tabular}

Here are the results of the price perception variable research, the answer choices are divided into 5 namely strongly disagree (SD), disagree (D), neutral (N), agree (A), strongly agree (SA)

Table 3.

Price Perception Descriptive Statistics Results

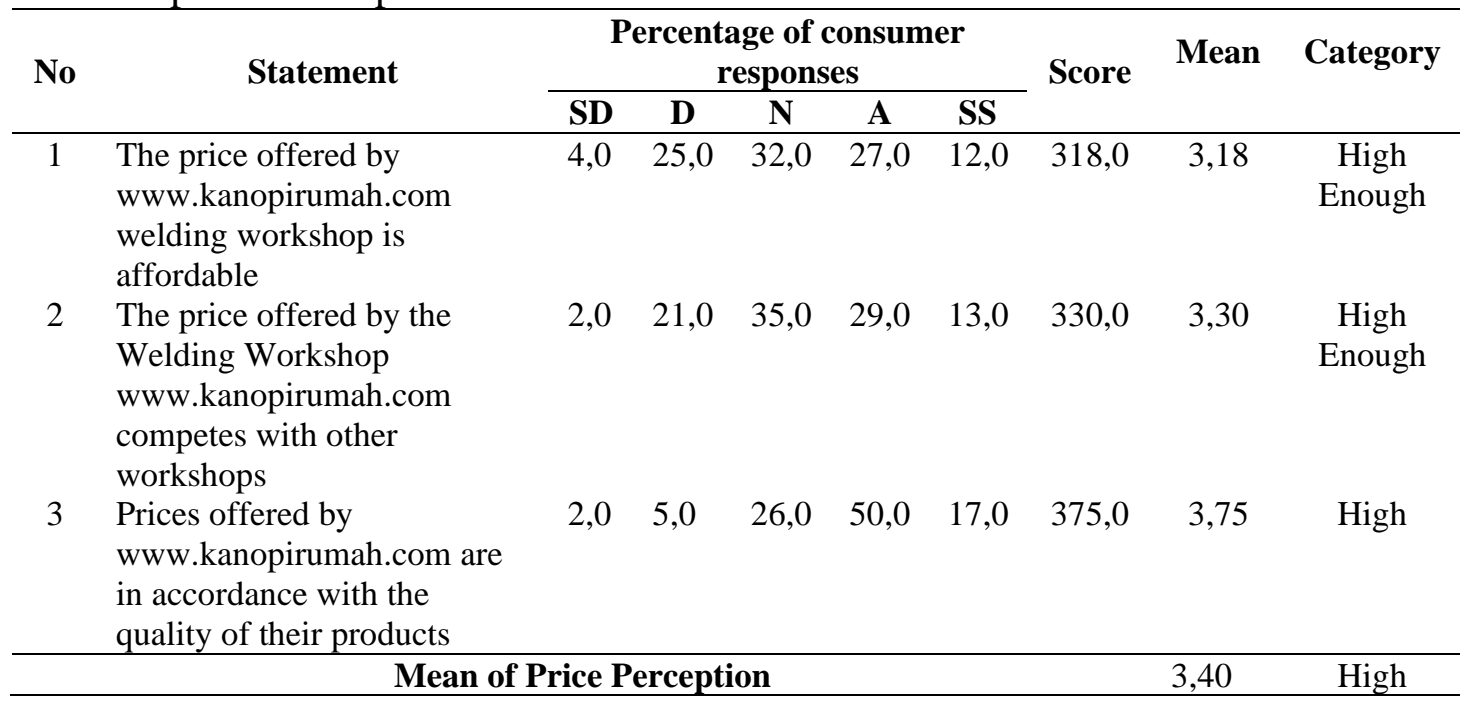


The following are the results of the trust variable research, the answer choices are divided into 5 namely strongly disagree (SD), disagree (D), neutral (N), agree (A), strongly agree (SA)

Table 4.

Confidence Descriptive Statistics Results

\begin{tabular}{|c|c|c|c|c|c|c|c|c|c|}
\hline \multirow[t]{2}{*}{ No } & \multirow{2}{*}{ Statement } & \multicolumn{5}{|c|}{$\begin{array}{l}\text { Percentage of consumer } \\
\text { responses }\end{array}$} & \multirow[t]{2}{*}{ Score } & \multirow[t]{2}{*}{ Mean } & \multirow[t]{2}{*}{ Category } \\
\hline & & SD & D & $\mathbf{N}$ & $\mathbf{A}$ & SS & & & \\
\hline 1 & $\begin{array}{l}\text { Welding employees at } \\
\text { www.kanopirumah.com can } \\
\text { be trusted in handling work }\end{array}$ & 2,0 & 16,0 & 45,0 & 22,0 & 15,0 & 332,0 & 3,32 & $\begin{array}{l}\text { High } \\
\text { Enough }\end{array}$ \\
\hline 2 & $\begin{array}{l}\text { Welding employees at } \\
\text { www.kanopirumah.com have } \\
\text { expertise in their fields }\end{array}$ & 2,0 & 13,0 & 12,0 & 56,0 & 17,0 & 373,0 & 3,73 & High \\
\hline 3 & $\begin{array}{l}\text { The Bengkel Bengkel } \\
\text { www.kanopirumah.com } \\
\text { employee is honest in } \\
\text { handling consumer work }\end{array}$ & 0 & 0 & 31,0 & 56,0 & 13,0 & 382,0 & 3,82 & High \\
\hline 4 & $\begin{array}{l}\text { The welding quality of } \\
\text { www.kanopirumah.com } \\
\text { employees is good }\end{array}$ & 4,0 & 14,0 & 38,0 & 29,0 & 15,0 & 337,0 & 3,37 & $\begin{array}{l}\text { High } \\
\text { Enough }\end{array}$ \\
\hline
\end{tabular}

Here are the results of the research variable purchase decision, the answer choices are divided into 5 namely strongly disagree (SD), disagree (D), neutral $(\mathrm{N})$, agree (A), strongly agree (SA)

Table 5.

Descriptive Statistics of Purchasing Decision Results

\begin{tabular}{|c|c|c|c|c|c|c|c|c|c|}
\hline \multirow[t]{2}{*}{ No } & \multirow[t]{2}{*}{ Statement } & \multicolumn{5}{|c|}{$\begin{array}{c}\text { Percentage of consumer } \\
\text { responses }\end{array}$} & \multirow[t]{2}{*}{ Score } & \multirow[t]{2}{*}{ Mean } & \multirow[t]{2}{*}{ Category } \\
\hline & & SD & D & $\mathbf{N}$ & $\mathbf{A}$ & SS & & & \\
\hline 1 & $\begin{array}{l}\text { Convinced and confident to } \\
\text { use services in the welding } \\
\text { workshop } \\
\text { www.kanopirumah.com }\end{array}$ & 3,0 & 15,0 & 42,0 & 29,0 & 11,0 & 330,0 & 3,30 & $\begin{array}{c}\text { High } \\
\text { Enough }\end{array}$ \\
\hline 2 & $\begin{array}{l}\text { The process of working in } \\
\text { the welding shop } \\
\text { www.kanopirumah.com is } \\
\text { fast }\end{array}$ & 1,0 & 5,0 & 26,0 & 54,0 & 14,0 & 375,0 & 3,75 & High \\
\hline 3 & $\begin{array}{l}\text { Decided to order at the } \\
\text { welding shop } \\
\text { www.kanopirumah.com }\end{array}$ & 3,0 & 14,0 & 40,0 & 27,0 & 16,0 & 339,0 & 3,39 & $\begin{array}{l}\text { High } \\
\text { Enough }\end{array}$ \\
\hline & Mean of $P$ & has & g Dec & sion & & & & 3,48 & High \\
\hline
\end{tabular}

\section{Regression Analysis}

Based on the results of the regression it can be made a linear equation between brand image, service quality, price perception and trust in the purchase decision as follows: $Y=0,216 X_{1}+0,214 X_{2}+0,246 X_{3}+0,303 X_{4}$ 
F-test results of 102.939 with sig. 0,000 smaller $(<)$ than $\alpha=0.05$. With this result, the Brand Image, Service Quality, Price Perception, and Trust affect the purchasing decisions simultaneously. This shows that the regression model used is fit or good.

Here are the results of the t-test: the brand image of the purchasing decision gets a value of 2,329 with sig. $0.022<\alpha=0.05$, so the hypothesis stating that brand image influences purchasing decisions is proven. Quality of service to the purchase decision obtained a value of 2,278 with sig. $0.025<\alpha=0.05$, so the hypothesis stating that service quality has an effect on purchasing decisions is proven. The price perception of the purchase decision obtained a value of 3,093 with sig. $0.003<\alpha=0.05$, so as to prove the hypothesis stating that price perceptions influence proved to purchase decisions. Trust in purchasing decisions obtained a value of 3,215 with sig. $0.002<\alpha=0.05$, thus proving the hypothesis which states that trust influences proved purchasing decisions.

The coefficient of determination can be seen in Adjusted R Square of 0.803. This result can be interpreted that brand image, service quality, price perception, and trust are able to explain purchasing decisions by $80.4 \%$ (0.804 x 100\%), while 19.6\% (100\% - 80.4\%) purchasing decisions are influenced by variables beyond brand image, service quality, price perception, and trust.

\section{CONCLUSION}

Based on the research results obtained that, brand image influences purchasing decisions with a t-test value of 2,329. Quality of service influences purchasing decisions with a t-test value of 2.278. Price perception influences purchasing decisions with a t-test value of 3.09. Ttrust affects the purchase decision with a t-test value of 3.215. Brand image, service quality, price perception, and trust influence purchasing decisions

\section{REFERENCES}

Achidah, N., Hasiolan, L. B., \& Warso, M. M. (2016). Pengaruh Promosi, Harga, Dan Desain Terhadap Keputusan Pembelian Sepeda Motor Mio GT. Journal Of Management.

Amrullah, A. R., \& Agustin, S. (2016). Pengaruh Kualitas Produk Harga dan Citra Merek terhadap Keputusan Pembelian Honda Beat. Jurnal Ilmu dan Riset Manajemen Sekolah Tinggi Ilmu Ekonomi Indonesia (STIESIA) Surabaya ISSN: 2461-0593.

Asshiddieqi, F., \& Mudiantono. (2012). Analisis Pengaruh Harga, Desain Produk Dan Citra Merek Terhadap Keputusan Pembelian ( Studi Kasus pada Produk Crooz di Distro Ultraa Store Semarang ). Diponegoro Journal of Management.

Brata, A. A. (2003). Dasar-Dasar Pelayanan Prima. (Jakarta: PT. Elex Media Komputindo, 2003).

Diza, F., Moniharapon, S., \& Ogi, I. W. J. (2016). Pengaruh Kualitas Pelayanan, Kualitas Produk Dan Kepercayaan Terhadap Kepuasan Konsumen (Studi Pada PT. FiFGROUP Cabang Manado). Jurnal Riset Ekonomi, Manajemen, Bisnis dan Akuntansi.

Fitria, Z. (2014). Keputusan Pembelian. Marketing Science.

Fristiana, D. A. (2012). Pengaruh Citra Merek dan Harga Terhadap Keputusan Pembelian Pada Ramai Swalayan Peterongan Semarang. Ilmu Administrasi Bisnis.

Giese, J., \& Cote, J. (2000). Defining consumer satisfaction. Academy of marketing science 
review.

Haviluddin;, H. M. S. A. (2014). Sistem Pendukung Keputusan Pembelian Notebook. Jurnal Informatika Mulawarman.

Kartikasari, D., Arifin, Z., \& Hidayat, K. (2013). Pengaruh Perilaku Konsumen Terhadap Keputusan Pembelian. Jurnal Administrasi Bisnis.

Komalasari, F. (2012). Pengaruh Bauran Pemasaran Terhadap keputusan Pembelian Produk Handphone Nokia Eseries. Jurnal Manajemen.

Kotler dan Amstrong. (2008). Prinsip-Prinsip Pemasaran Jilid I. In Erlangga.

Mamahit, P., Soegoto, A. S., \& Tumbuan, W. A. (2015). Pengaruh Brand Image, Brand Trust, Dan Kualitas Produk Terhadap Keputusan Pembelian Mobil Toyota All New Yaris Pada Pt. Hasjrat Abadi Manado. Jurnal Philius Mamahit1, Agus Supandi Soegoto2, Willem Alfa Tumbuan3.

Nurmadina. (2016). Analisis Faktor-Faktor yang Mempengaruhi Keputusan Pembelian Secara Online.

Peter, J. P., \& Olson, J. C. (2014). Perilaku Konsumen dan Strategi Pemasaran. In salemba empat.

Puccinelli, N. M., Goodstein, R. C., Grewal, D., Price, R., Raghubir, P., \& Stewart, D. (2009). Customer Experience Management in Retailing: Understanding the Buying Process. Journal of Retailing. https://doi.org/10.1016/j.jretai.2008.11.003

Riyono, \& Budiharja, G. E. (2016). Pengaruh Kualitas Produk, Harga, Promosi Dan Brand Image Terhadap Keputusan Pembelian Produk Aqua Di Kota Pati. Jurnal Stie Semarang.

Schiffman, L., \& Kanuk, L. L. (2007). Perilaku Konsumen Edisi Kedua. In PT. Indeks Gramedia.

Selang, C. A. (2013). Bauran Pemasaran (Marketing Mix) Pengaruhnya Terhadap Loyalitas Konsumen Pada Fresh Mart Bahu Mall Manado. Jurnal EMBA.

Setiadi, N. J. (2003). Perilaku Konsumen. Aplikasi Manajemen.

Soegoto, A. S., Mandey, S., \& Sari, R. L. (2014). Citra Merek, Harga Dan Promosi Pengaruhnya Terhadap Keputusan Pembelian Perhiasan Emas Pada Pt. Pegadaian (Persero) Cabang Manado Utara. Jurnal Riset Ekonomi, Manajemen, Bisnis dan Akuntansi.

Subianto, T. (2007). Studi Tentang Perilaku Konsumen Beserta Implikasinya Terhadap Keputusan Pembelian. Ekonomi Modernisasi.

Sumarwan, U. (2014). Model Keputusan Konsumen. Perilaku konsumen.

Sumiati. (2016). Pengaruh Kualitas Produk Dan Harga Terhadap Keputusan Pembelian Produk Kosmetik Wardah Di Kota Bangkalan Madura. Jurnal Ekonomi \& Bisnis.

Sunarsi, D. (2018). Pengaruh rekrutmen, seleksi dan pelatihan terhadap produktivitas kerja karyawan. KREATIF: Jurnal Ilmiah Prodi Manajemen Universitas Pamulang, 6(1), 1431.

Suryonaningsih, E. (2016). Effect of Price and Image Brand on Consumer Satisfaction. Journal of Management. 


\section{Pinisi Discretion Review}

Volume 2, Issue 1, September, 2018 Page. 17- 24

Sutisna. (2003). Perilaku Konsumen: Teori dan penerapannya dalam Pemasaran. Ghalia Indonesia, Jakarta. https://doi.org/10.1007/BF01013984

Wijaya, D. N., Sunarti, \& Pangestuti, E. (2018). Pengaruh Gaya Hidup dan Motivasi Terhadap Keputusan Pembelian (Survei pada Konsumen Starbucks, Kota Malang). Administrasi Bisnis. 